\title{
Transglutaminases: recent achievements and new sources
}

\author{
Ivone M. Martins • Mauro Matos • Rodrigo Costa • \\ Fátima Silva • Ananias Pascoal • Letícia M. Estevinho • \\ Altino Branco Choupina
}

Received: 19 March 2014 /Revised: 10 June 2014 / Accepted: 11 June 2014 /Published online: 25 June 2014

(C) Springer-Verlag Berlin Heidelberg 2014

\begin{abstract}
Transglutaminases are a family of enzymes (EC 2.3.2.13), widely distributed in various organs, tissues, and body fluids, that catalyze the formation of a covalent bond between a free amine group and the $\gamma$-carboxamide group of protein or peptide-bound glutamine. Besides forming these bonds, that exhibit high resistance to proteolytic degradation, transglutaminases also form extensively cross-linked, generally insoluble, protein biopolymers that are indispensable for the organism to create barriers and stable structures. The extremely high cost of transglutaminase of animal origin has hampered its wider application and has initiated efforts to find an enzyme of microbial origin. Since the early 1990s, many microbial transglutaminase-producing strains have been found, and production processes have been optimized. This has resulted in a rapidly increasing number of applications of transglutaminase in the food sector. However, applications of microbial transglutaminase in other sectors have also been explored, but in a much lesser extent. Our group has identified a transglutaminase in the oomycete Phytophthora cinnamomi, which is able to induct defense responses and disease-like symptoms. In this mini-review, we report the achievements
\end{abstract}

I. M. Martins • M. Matos · F. Silva • A. Pascoal • L. M. Estevinho • A. B. Choupina $(\bowtie)$

CIMO-Mountain Research Center, Agricultural College of Bragança, Polytechnic Institute of Bragança, Campus de Santa Apolónia, Apartado 1172, 5301-855 Bragança, Portugal e-mail: albracho@ipb.pt

I. M. Martins

CEB - Centre of Biological Engineering, University of Minho, 4710-057 Braga, Portugal

\section{R. Costa}

Department of Microbiology and Genetics, CIETUS-IBSAL, University of Salamanca/CSIC, Plaza de los Drs. de la Reina s/n, 37007 Salamanca, Spain in this area in order to illustrate the importance and the versatility of transglutaminases.

Keywords Transglutaminase $\cdot$ MTG $\cdot$ Phytophthora cinnamomi $\cdot$ Applications

\section{Introduction}

Transglutaminases (TGases), also named protein-glutamine $\gamma$ glutamyltransferases, are enzymes belonging to the proteases class that catalyze post-translational modifications in many proteins by inter- or intramolecular cross-linking through acyl-transfer between $y$-carboxyamide groups of glutamine residues and $\varepsilon$-amino groups of lysines, or other primary amine, resulting in the formation of $\gamma$-glutamyl- $\varepsilon$-lysine peptide chain bridges (Beninati et al. 2009; Campos et al. 2010; $\mathrm{Hu}$ et al. 2011; Jung et al. 2012; Li et al. 2013; Lorand and Graham 2003). In the latter case, it is able to modify the protein substrate by "cationization" or by forming inter- or intramolecular bridges through polyamines of different length (Serafini-Fracassini et al. 2009). The results of this activity are the modification of the protein conformation and other more extensive conformational changes, due to bonding between the same and different proteins, forming high molecular weight conjugates (Carvajal et al. 2011).

TGases have been found in prokaryotes and eukaryotes, including guinea pig (Folk and Cole 1966), and were actually first extracted from this animal's liver in 1973 (Folk and Chung 1973). This TGase was the only form arriving at the market by the end of the $80 \mathrm{~s}$, not arousing much interest from the industrial point of view, since it was very expensive. In addition it was a $\mathrm{Ca}^{2+}$-dependent enzyme, which led to the precipitation of proteins of some foods containing casein, soybean globulin, or myosin (Faria 2010; Serafini-Fracassini and Del Duca 2008). 
Nevertheless, TGases are known to be widely distributed in nature, being found in mammalian, vertebrates, invertebrates, mollusks, plants, and microorganisms (Folk et al. 1980; Icekson and Apelbaum 1987; Porta et al. 2013; Yasueda et al. 1994), and were reported as a single-chain polypeptide consisting of 331 amino acids (Della Mea et al. 2004; Macedo and Sato 2005).

Although, it is associated to food industry, as a food additive (texturing agent), and in wool textiles and biopolymers (Carvajal et al. 2011), the interest in these enzymes is also focused on several biological processes (blood clotting, wound healing, epidermal keratinization, curing membranes) and clinical applications such as neurodegenerative diseases and blood coagulation disorders, bone tissue healing processes and cell differentiation processes, tissue stabilization, and even in apoptosis (Brunner et al. 2002; Csosz et al. 2008; Lorand and Graham 2003). In addition, TGases are considered as responsible for growth regulation, differentiation, and cell proliferation, as well as having an important role in allergies prevention.

\section{Mechanism of action of TGases}

TGases catalyzes post-translational cross-link reactions between two substrates that can be two proteins or two residues of the same protein, involving lysine and glutamine (SerafiniFracassini and Del Duca 2008). These cross-links occur along time, and one critical step is the process of cell stabilization, between the extensive range cross-existing $\varepsilon$ - $(\gamma$-Glu $)$ Lys and $N, N$-bis(7-Glu)amine, that are the most frequent among those, caused by the catalytic action of the enzyme.

The inter- and intraprotein cross-links of TGases are catalyzed by inducing a modification of their structure at the molecular level thereby affecting the functional properties of these proteins, allowing further structural forms and creating polymers of high molecular weight (Faria 2010). It is the original molecular structure of proteins that determines whether a TGase cross-linking is possible and to what extent (Macedo and Sato 2005). In food, protein cross-linking occurs before the other reactions (Fig. 1).

Several studies revealed that the level of $\varepsilon-(\gamma-\mathrm{Glu}) \mathrm{Lys}$ is rather high in processed, especially cooked, foods compared to raw materials (Sakamoto et al. 1995; Seguro et al. 1996b). Other studies reported that humans have long been ingesting $\varepsilon-(\gamma$ Glu)Lys cross-links, and both of the cross-linked proteins and the lysine in the $\varepsilon$ - $(\gamma-\mathrm{Glu})$ Lys moiety have been confirmed to be metabolized in the organism (Seguro et al. 1995, 1996a).

\section{Microbial transglutaminase}

The search for novel chemotherapeutic and chemoprevention drugs with less toxicity, particularly from natural sources, is of great importance. Some literature data reveals the important anti-cancer effects of phytochemicals linked to the reduction of polyamine production and to the induction of tumor cell differentiation, through the activation of intracellular TGases (Facchiano et al. 2006; Lentini et al. 2010). Lentini et al. (2009) reported the direct correlation between TGase activation, reduction of cancer growth, and stimulation of melanoma cell differentiation.

Studies conducted in this field performed the isolation of microbial TGases (MTG) from Streptoverticillium sp. (Ando et al. 1989; Folk and Cole 1966) and from Bacillus sp. (Marx et al. 2008). Obtaining TGases by microorganisms has become a step of great industrial importance, from Streptoverticillium S-8112 (an actinomycete isolated from the soil), since it can be isolated as enzyme $\mathrm{Ca}^{2+}$-independent, with simplified purification procedures, reducing the costs. MTG showed to be able to make cross-links in the majority of food proteins such as caseins, soybean globulin, gluten, actins, myosin, and egg proteins, as efficiently as the animalderived mammals TGases.

Protein cross-linking catalyzed by MTG has attracted the greatest interest, owing its application in food and industrial processes (Camposa et al. 2013). Due to their effects on the physical and chemical properties of proteins, they have many biotechnological applications particularly in the food processing industry, in medicine, and in cosmetics, increasing the demand for an inexpensive, efficient, and safe source of recombinant enzymes (Capell et al. 2004; Faria 2010; Serafini-Fracassini and Del Duca 2008; Shleikin and Danilov 2011).

Regarding their application in medicine, the metabolites produced by Streptoverticillium sp. have an anti-inflammatory effect (Da Cruz et al. 2013). Recently, new data was published about the importance of TGases in chronic inflammatory diseases, in wound healing, in repair of tissues and development of fibrosis and autoimmune reactions, in chronic degenerative diseases (arthritis, atherosclerosis, and neurodegenerative states), and in oncologic pathology (Shleikin and Danilov 2011). In addition, it is known that TGase causes modification of surface viral glycoproteins gp41 and gp120 that mediate penetration of HIV into cell (Shleikin and Danilov 2011; Tabolacci et al. 2012).

The reaction mechanism of all known TGases is based on a Cys-His-Asp triad or, less frequently, a Cys-His dyad. Nucleophilic attack on the substrate is performed by the sulfhydryl group of the cysteine following activation by a thiolate-imidazolium ion pair involving the histidine side chain. The cysteine and the histidine residues are principally involved in the acyl-transfer reaction, where the aspartic acid residue hydrogen bonds with the histidine, maintaining a catalytically competent orientation. The crystal structure of MTG revealed that this triad is not conserved; rather, it was proposed that MTG uses a cysteine protease-like mechanism 
a<smiles>[Z][C@H](C)[C@@H](C)[C@@H](C)C(=O)N[PH2+]N</smiles>

b

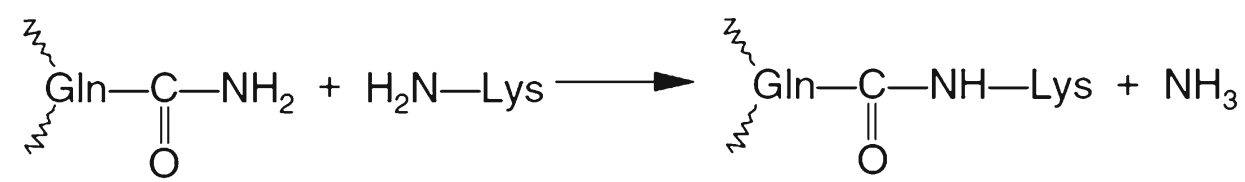

C<smiles>[Z]C(C)[In]C(N)=O</smiles>

Fig. 1 Reactions catalyzed by TGase: catalysis of acyl-transfer reactions between the $\gamma$-carboxyamide group of peptide or protein-bound glutamine (acyl donor) and primary amines (acyl acceptor) including the $\varepsilon$ amino group of lysine residues (a); when the $\varepsilon$-amino group of proteinbound lysine reacts as an acyl acceptor, intramolecular and/or

in which Asp plays the role of the histidine residue in factor XIII-like TGases (Rachel and Pelletier 2013) (Fig. 2).

Concerning the substrates for MTG reactions, recent studies have shown that among milk proteins, casein is the best for binding while among the animal tissue are gelatin and myosin. Also, well bound are soybean globulins, egg proteins, gliadin, and wheat glutenin (Lim et al. 2011; Shleikin and Danilov 2011). Thus, MTG-induced gelation, performed under mild conditions, may be a better alternative to encapsulate probiotic cells. Li et al. (2013) reported that the MTG produced by Streptomyces mobaraensis is commercially available and widely used in the food industry, biopolymers and cosmetics, clinical applications, and wool textiles. With respect to TGase heterologous production, only TGase from Streptoverticillium sp. is currently commercially available (Kobayashi et al. 1998; Kuraishi et al. 2001), with a low production by overexpression in Escherichia coli (Yokoyama et al. 2000). However, in the last decade, the interest in TGases of plants and oomycetes has increased.

\section{TGase in plants}

TGases and their functionality have been less studied in plants rather than in humans and animals (Carvajal et al. 2011). TGase in plants has been studied since 1987, with primary focus on the molecular mechanisms linking the protein changes with polyamines to form inter- and intramolecular bonds, influencing the growth and differentiation of plants (Brunner et al. 2002; Serafini-Fracassini and Del Duca 2008). The physiological role of TGase in plants appears to be related to photosynthesis, fertilization, response to abiotic and biotic stresses, senescence, and programmed cell death (Beninati et al. 2013).
Fig. 2 Crystal structure of MTG (PDB ID: 3 IU0). The active site of the zymogen is covered (a) by an $\alpha$-helix (gold), which is cleaved upon activation, exposing the active site cysteine residue (b, yellow spheres) that is critical for activity. Figure reprinted from (Rachel and Pelletier 2013)
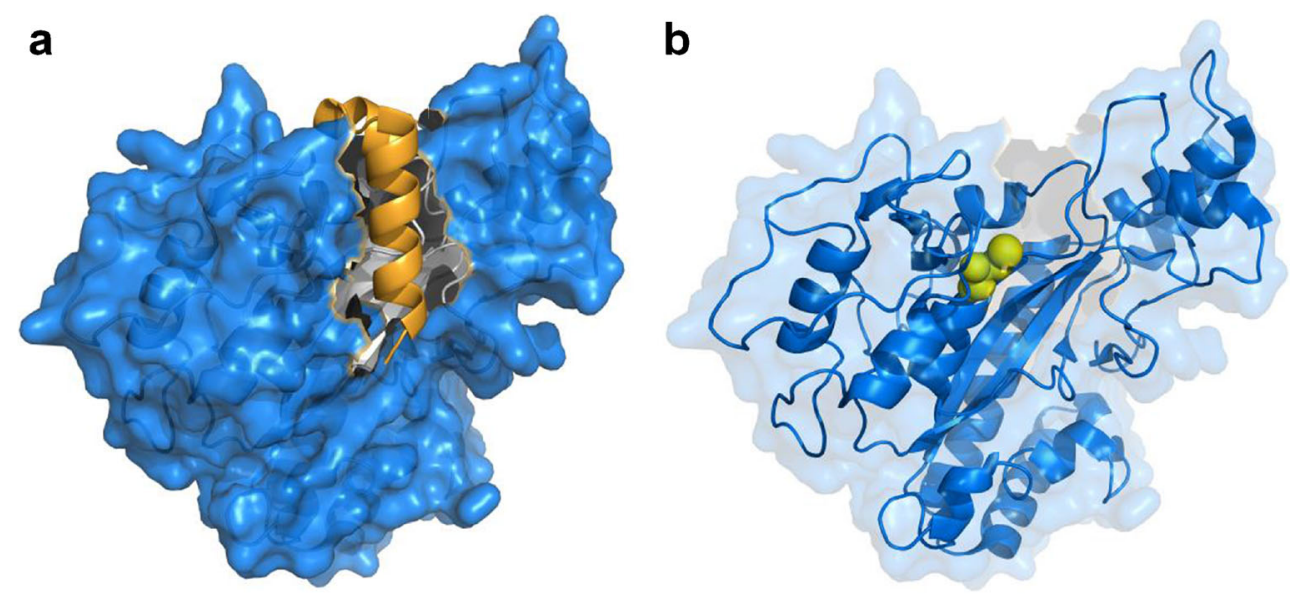
The few TGases sequenced by plants have little similarity with the animal enzymes but can share an homologous structure, since they have functional similarities, among which (1) the production of derivatives of glutamyl-polyamine reaction, (2) being recognized by antibodies of animal TGase, and (3) being $\mathrm{Ca}^{2+}$-dependent (Serafini-Fracassini and Del Duca 2008). Therefore, it is difficult to obtain information of plant TGases through homologous comparison with other sources. However, most of its features and properties remain a mystery. It is known that TGases have a ubiquitous character and are present in various structures of plants involved in specific processes of changes in the protein structure. In chloroplasts, despite its precise function is unclear, TGase appears to stabilize the photosynthetic complexes and ribulose bisphosphate carboxylase/oxygenase, being regulated by light and other factors, possibly exerting a positive effect on photosynthesis and photoprotection (Beninati et al. 2013; Campos et al. 2010). In the cytosol, TGase modifies cytoskeletal proteins as observed in the pollen tube which regulates the growth; furthermore, some reports suggest an involvement in the pollen tube cell wall construction/organization (Del Duca et al. 2009; Di Sandro et al. 2010; Faria 2010; SerafiniFracassini and Del Duca 2008). Other features are reported, highlighting the hypersensitive response which consists of programmed cell death upon infection by plant pathogens.

\section{TGase in Phytophthora}

Phytophthora species are pathogens that infect various plants, leading to major economic and environmental damage (Reiss et al. 2011). In recent years several studies have been undertaken, linking interactions between Phytophthora and resistant plants in order to understand the mechanisms of infection, hypersensitive response, and resistance of the host (Kamoun 2001). Phylogenetic studies, developed by Kamoun, proved that oomycetes have developed unique capabilities to infect plants as well as unique mechanisms to achieve (1) hypersensitive response, (2) response with hypersensitive cell death, and (3) faster hypersensitive response with programmed apoptosis. The immune response consists of the recognition of pathogen-associated molecular patterns (PAMPs) from the infected organism and consequent attack response, provided by the infected cells (Bent and Mackey 2007; Chisholm et al. 2006). The faster the immune response is, the smaller will be the proliferation of the pathogen agent.

A fragment of an oligopeptide, called Pep-13, was identified inside of glycoprotein gp42 present in the cell wall of Phytophthora sojae (Brunner et al. 2002). When introduced into salsa, Pep-13 induced a number of defense mechanisms, leading to a hypersensitive response, followed by death of the infected cells. Brunner and collaborators determinate that gp42 is a $\mathrm{Ca}^{2+}$-dependent TGase, the first identified in oomycetes. In addition, with the induction of gene mutations in Pep-13, they found that the amino acids responsible for inducing an immune response in plants are the same amino acids needed by the TGase to initiate the activity (Brunner et al. 2002). Apart from this factor, Pep-13 has similar evolutionary characteristics to PAMPs, starting an immune response in vertebrates and invertebrates organisms. Summarizing, the plants can recognize PAMPs with similar characteristics, known by trigger innate immune responses in animals. This factor is of great importance, since it relates to the ability of immune response of different realms (Brunner et al. 2002).

TGases structural sequences with elicitin activity, associated to plant defense mechanisms, were isolated and characterized by our group in Phytophthora cinnamomi (partial cds). Thermal asymmetric interlaced-PCR, and hemispecific PCR amplification protocols, that combine nested insert ionspecific primers (designed in highly conserved region of Phytophthora transglutaminases), with degenerate primers, were used to amplify DNA flanking of a known sequence using genomic P. cinnamomi DNA as template (Choupina et al. 2014; Martins et al. 2014). In this process, a 2,218-bp DNA fragment was sequenced (GenBank: AM403129.1, unpublished results). That fragment encodes a 533 deduced amino acid protein which includes an ORF with high homology with P. sojae (70 \%), Phytophthora megasperma (70\%), and Phytophthora infestans (61\%) transglutaminases, besides a deduced similar structure. Alignment of a transglutaminase gene with several transglutaminase proteins revealed that our protein contains the conserved domain [GT]-Q[CA]-W-V$\mathrm{X}-[\mathrm{SA}]-[\mathrm{GAS}]-[\mathrm{VT}]-\mathrm{x}(2)-\mathrm{T}-\mathrm{x}[\mathrm{LMSC}]-\mathrm{R}-[\mathrm{CSAG}]-[\mathrm{LV}]-\mathrm{G}$, (Fig. 3).

\section{TGase application in food processing industry}

TGase is classified, by some authors, as glue to meat, being increasingly used in gastronomy. As previously referred, it is able to form stable and covalent links between proteins. This transformation operates in all types of food proteins (fish, meat, tofu, jelly, flours). Basically, in foods that contain proteins, TGase is responsible for the polymer formation, raising interest in food processing (Lorenzen 2007). Its application modifies food characteristics, acting in terms of solubility and hydration capacity, among others (Faria 2010).

Because the $\varepsilon$-(y-Glu)Lys (inter- and intramolecular) are covalent bonds, they are more stable than ionic or hydrophobic bonds. These connections, even in small amounts, can have a significant effect in food properties (Faria 2010; Kuraishi et al. 1996, 2001). Functionality of the proteins can be drastically altered, causing dramatic changes in the size, organization, stability, and other protein properties (Truong et al. 2004). Due to this ability to change the functionality of 


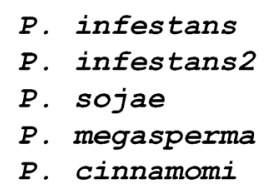

P. infestans

P. infestans 2

P. sojae

$P$. megasperma

P. cinnamomi

P. infestans

P. infestans 2

P. sojae

$P$. megasperma

P. cinnamomi

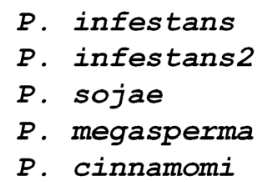

MVYT PRAYLVSAAVALVAMQLQQTAATSLFYDPETISGTDGTISGKF PARGAEVADQDCT 60 MVFSPSTYLVSAAVACVALQMQQASAGSLFYGVTTVAKTQNEITDKSPFYGSDVADQDCA 60 MVYSPSTYLISAVVAAVALQMQQTAAISLYYTPFTVSDTTNEITDKFPAYGADVADQDCI 60 MVYSPSTYLISAVVAAVALQMQQTAATSLYYTPFTVSDTTNEITDKFPAYGADVADQDCI 60 MVYSPSTYLISAVVAAVALQMQQTTATSLYYTPFTVSDTTDKITNKFPGYGGRVTEQDCL 60

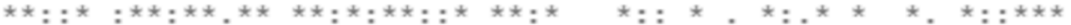

FTVEVDPTLPDIATISTVPVTYPGLLANLTTVPSEPLFTKVGTAVLSEPI PAIDADQDSY 120 IQVTVDPTLPNITTILPE PVEYPDLLANLTTAPADPVFTKVGEADVSEDCPTKDADLDAY 120 IKVEVDPTLPNITTISPVPVTYPDLLANLTTAPADPVYSKVGSAILKEDAPATDAEQDSY 120 IKVEVDPTLPNITTISPVPVTYPDLLANLTTAPADPVYSKVGSAILKEDAPATDAEQDSY 120 IQVNLDPTLPNITTI PSAPVEYPDLIANLTTAPVEPLCSKVGTIELSVETPAVDADQDAY 120

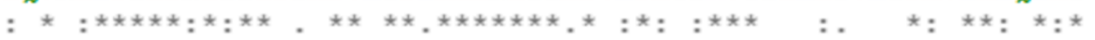

VGKSTSTPVTVPDTKTGVSTPSIVKSATDCATGWEDSSTTQAKMEKKRRLEANSNKDIAK 180 LDS------TI PWTNTGIPTKIGVETVKDCATGWDDT-AIQAKVEKKRRLEANGNADIAK 173 ISAN------IPDTN-GKVGKPGLSDPKDCATGWDDA-QTARKLETKRRLEANGNQDIAK 172 ISAN------IPDTN-GKVGKPGLSDPKDCATGWDDA-QTARKLETKRRLEANGNQDIAK 172 VGKI-----VLSSPVIAPTNKIGIG-HSDCATGWEDT-QATRKLQTKRQLEANANQDIAK 173 : $\quad$. . . : : .******:*: $*:: *_{* *}: * * * * . * * * * *$

LEAYFGTKMETTLKNLPTKAVHT SSPAGPYWPTYQDSINVVWSQGQP-SPAEKYAKAFG 239 LEAFFGTKMEMTLKDLPTQAVHTPSPWAGPYWPTYQDSINVVWSQGQP-SPAEKYAKAFG 232 LEAYFGTKMEMTLKDLPTVGVHTPSPWAGPYWPTYQDSINVQWSQGQP-SAAEKYAKAFG 231 LEAYFGTKMEMTLKDLPTVGVHTPSPWAGPYWPTYQDSINVQWSQGQP-SAAEKYAKAFG 231 LEAYFGTKMEMNLQKLPTVGVYTPSPWAGPYWPTYQDSINVCLGARDSRVLLRSTPKALR 233

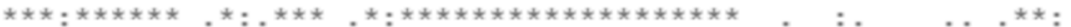

Fig. 3 Multiple sequence alignment of transglutaminase from Phytophthora sp.

food proteins, what is one of the most innovative uses of enzymes in food technology during the last decade, TGases have been the object of study in processed food containing soybean protein, myosin, gluten, globulin, whey proteins, and casein, (Lorenzen 2007; Macedo and Sato 2005). However, despite its beneficial application, the usage of TGases as food additive has to be declared to ensure transparency for the consumers.

Concerning the food processing industry, MTG is active over a wide range of temperatures and stable between $\mathrm{pH} 5$ and 9, which is the $\mathrm{pH}$ range for most food processing (Ando et al. 1989; Seguro et al. 1996b). According to Ajinomoto (2011), TGase, when added to food, influences the following properties:

1. Gelatinization capacity: a protein that is initially unable to form gel by itself can form gel and become firmer.

2. Viscosity: when increasing the molecular weight of the protein, the protein solution viscosity increases.

3. Thermal stability: the covalent bonds formed, inter- and intramolecular, are stable as temperature changes.

4. Capacity of water retention: the capacity of water retention increases, independently of changes in temperature or physical forces.

5. Nutritional value: the polymerization by biological transformations is considered safer than by chemical transformations.

Ozer et al. (2007) and Yüksel and Erdem (2010) reported that the cross-linking reaction induced by TGase resulted in an increase of the gel strength, stability, viscosity, and waterholding capacity of yogurt . Indeed, previous studies reporting the effects of TGase on yogurt have been published (Lauber et al. 2000; Lorenzen et al. 2002). In the processing of prepared foods, especially meat products, salt and/or some phosphates are usually added to improve or increase the waterholding capacity, binding, consistency, and overall texture (Kuraishi et al. 2001). Among dairy proteins, casein can be easily cross-linked by TGase, mainly owing to its highly accessible and flexible open chain (Jaros et al. 2007). Furthermore, the use of this enzyme was shown to increase the shelf life of certain products and reduce the allergen potential for others (Macedo and Sato 2005). Also, TGase could prevent syneresis improving viscosity, water-holding capacity, and preventing ice crystal growth, so it is expected that TGase may allow the replacement of stabilizers used during the manufacture of dairy products to enhance and maintain certain characteristics (Kuraishi et al. 2001).

Kuraishi et al. (2001) reported that TGase has been used to modify the functional properties of many food proteins in seafood, surimi products, meat products, noodles/pasta, dairy products, baked goods, and so on . MTG also has been reported as useful to improve textural properties of protein gel-based dairy products (Castro-Briones et al. 2009; Yew et al. 2011; Yokoyama et al. 2004; Zhang et al. 2013). Other studies reported some applications in seafood products, allowing changing their texture, especially in retorted products, while frozen foods are prevented to some extent 
by soaking raw materials in a solution of TGase and caseinate (Kurakata et al. 1995; Sakai et al. 1996). TGase is also used to treat salted cod roe and are widely used in noodles and pasta production in Japan (Kuraishi et al. 2001). More industrial applications of TGase have been well reviewed by Nielsen (1995) and Zhu et al. (1995).

\section{Pharmacological application of TGase}

TGases are involved in diverse physiological and physiopathological processes, becoming a target of interest with high potential for therapeutic use.

One of the best-known TGases is factor XIII in human blood (Chung 1972). Factor XIII helps to stop bleeding by forming cross-links of fibrin molecules and stabilizing fibrin polymers (Faria 2010; Kuraishi et al. 2001). In addition, this enzyme is involved in the prevention of blood loss from traumatized vessels by formation of fibrin clot at blood coagulation, activation of platelets, and layering of granulation tissues representing primary healing of local lesion (Shleikin and Danilov 2011). Besides, factor XIII has been applied in the substitutive therapy at rare genetic defects of blood coagulation caused by the absence of TGase in blood plasma (Shleikin and Danilov 2011).

TGase also presents several applications at the pharmacological level. It was developed by Noguchi et al. (1992), a material that promotes absorption of minerals by the human body. This material was obtained through the use of TGase in casein; it promotes mineral absorption in the intestine and can be used in the food industry and pharmaceutical for mineral supplements for children and adults, reducing the allergenicity of certain proteins (Macedo and Sato 2005). Some studies have shown that TGase has multiple physiologic functions and is associated with cancer cell survival and drug resistance (Mehta et al. 2004), anti-apoptotic effects by promoting interactions between cell-surface integrins (Akimov and Belkin $2001)$ by interacting with the retinoblastoma $(\mathrm{Rb})$ protein (Boehm et al. 2002), or by downregulation of caspase 3 (Yamaguchi and Wang 2006). Also, it is highly expressed in drug-resistant cancer cells (Kim et al. 2006; Mehta et al. 2004). Other studies reported the use of TGase for grafting of gelatin or ovalbumin with chitosan to prepare functional biomaterials (Chen et al. 2003; Di Pierro et al. 2007). Commercial application of TGases has been constantly increased at a rising rate, in particular for the development of new vaccination strategies in infectious and viral infections. For example, it is known that some bacterial toxins, including the cytotoxic factor 1 of E. coli, act as TGase (Shleikin and Danilov 2011).

\section{Conclusions}

The growing world population leads to concerns for new sources of food. The search for new sources of proteins and the profitability of existing is an essential priority. Advances in science have contributed greatly to produce sources of proteins and meat alternatives in order to address the protein deficiency in the human diet as well as contribute to the development of healthier products, providing health and wellness. Targeting all these aspects, proteins modified with enzymes, notably through the use microbial transglutaminases, are one of the most promising alternatives for the production of new protein foods. On another hand, the potential of transglutaminase is not confined to the food and pharmacological applications. Recent findings relate the importance of this enzyme in the plant's hypersensitive response, to diseases responsible for the devastation of crops, and by introducing new concepts in cross-immune response to different realms.

With all these findings and given the ubiquitous nature of TGases in the activity of all organisms, it becomes essential to classify all the features and properties of this enzyme.

\section{References}

Akimov SS, Belkin AM (2001) Cell-surface transglutaminase promotes fibronectin assembly via interaction with the gelatin-binding domain of fibronectin: a role in TGFbeta-dependent matrix deposition. J Cell Sci 114(16):2989-3000

Ando H, Adachi M, Umeda K, Matsuura A, Nonaka M, Uchio R, Tanaka H, Motoli M (1989) Purification and characteristics of a novel transglutaminase derived from microorganisms. Agric Biol Chem 53:2613-2617

Beninati S, Bergamini CM, Piacentini M (2009) An overview of the first 50 years of transglutaminase research. Amino Acids 36(4):591-598

Beninati S, Iorio RA, Tasco G, Serafini-Fracassini D, Casadio R, Del Duca S (2013) Expression of different forms of transglutaminases by immature cells of Helianthus tuberosus sprout apices. Amino Acids 44(1):271-283

Bent AF, Mackey D (2007) Elicitors, effectors, and R genes: the new paradigm and a lifetime supply of questions. Annu Rev Phytopathol 45:399-436

Boehm JE, Singh U, Combs C, Antonyak MA, Cerione RA (2002) Tissue transglutaminase protects against apoptosis by modifying the tumor suppressor protein p110 Rb. J Biol Chem 277(23):20127-20130

Brunner F, Rosahl S, Lee J, Rudd JJ, Geiler C, Kauppinen S, Rasmussen G, Scheel D, Nurnberger T (2002) Pep-13, a plant defense-inducing pathogen-associated pattern from Phytophthora transglutaminases. EMBO J 21(24):6681-6688

Campos A, Carvajal-Vallejos PK, Villalobos E, Franco CF, Almeida AM, Coelho AV, Torne JM, Santos M (2010) Characterisation of Zea mays L. plastidial transglutaminase: interactions with thylakoid membrane proteins. Plant Biol 12(5):708-716

Camposa N, Castañón S, Urretab I, Santosa M, Torné JM (2013) Rice transglutaminase gene: identification, protein expression, functionality, light dependence and specific cell location. Plant Sci 205-206: 97-110 
Capell T, Claparols I, Del Duca S, Bassie L, Miro B, RodriguezMontesinos J, Christou P, Serafini-Fracassini D (2004) Producing transglutaminases by molecular farming in plants: minireview article. Amino Acids 26(4):419-423

Carvajal P, Gibert J, Campos N, Lopera O, Barbera E, Torne JM, Santos M (2011) Activity of maize transglutaminase overexpressed in Escherichia coli inclusion bodies: an alternative to protein refolding. Biotechnol Prog 27(1):232-240

Castro-Briones M, Calderon GN, Velazquez G, Salud-Rubio M, Vázquez M, Ramirez JA (2009) Effect of setting conditions using microbial transglutaminase during obtention of beef gels. J Food Process Eng $32: 221-234$

Chen T, Embree HD, Brown EM, Taylor MM, Payne GF (2003) Enzymecatalyzed gel formation of gelatin and chitosan: potential for in situ applications. Biomaterials 24(17):2831-2841

Chisholm ST, Coaker G, Day B, Staskawicz BJ (2006) Host-microbe interactions: shaping the evolution of the plant immune response. Cell 124(4):803-814

Choupina AB, Estevinho L, Martins IM (2014) Scientifically advanced solutions for chestnut ink disease. Appl Microbiol Biotechnol 98(9): 3905-3909

Chung SI (1972) Comparative studies on tissue transglutaminase and factor XIII. Ann N Y Acad Sci 202:240-255

Csosz E, Bagossi P, Nagy Z, Dosztanyi Z, Simon I, Fesus L (2008) Substrate preference of transglutaminase 2 revealed by logistic regression analysis and intrinsic disorder examination. J Mol Biol 383(2):390-402

Da Cruz RB, Galdino PM, Penna KG, Hoffmann K, Costa EA, Bataus LA (2013) Acetone extract from Streptoverticillium sp., a bacterium isolated from Brazilian Cerrado soil, induces anti-inflammatory activity in mice. An Acad Bras Cienc 85(2):595-603

Del Duca S, Serafini-Fracassini D, Bonner P, Cresti M, Cai G (2009) Effects of post-translational modifications catalysed by pollen transglutaminase on the functional properties of microtubules and actin filaments. Biochem J 418(3):651-664

Della Mea M, Caparros-Ruiz D, Claparols I, Serafini-Fracassini D, Rigau J (2004) AtPng1p. The first plant transglutaminase. Plant Physiol 135(4):2046-2054

Di Pierro P, Chico B, Villalonga R, Mariniello L, Masia P, Porta R (2007) Transglutaminase-catalyzed preparation of chitosan-ovalbumin films. Enzym Microb Technol 40(3):437-441

Di Sandro A, Del Duca S, Verderio E, Hargreaves AJ, Scarpellini A, Cai G, Cresti M, Faleri C, Iorio RA, Hirose S, Furutani Y, Coutts IG, Griffin M, Bonner PL, Serafini-Fracassini D (2010) An extracellular transglutaminase is required for apple pollen tube growth. Biochem J 429(2):261-271

Facchiano F, Facchiano A, Facchiano AM (2006) The role of transglutaminase-2 and its substrates in human diseases. Front Biosci 11:1758-1773

Faria SD (2010) Estudo dos Efeitos da Aplicação de Transglutaminase em Bebida Láctea Fermentada com Alto Conteudo de Soro. Master, Escola de Engenharia Mauá de Tecnologia

Folk JE, Chung SI (1973) Molecular and catalytic properties of transglutaminases. Adv Enzymol Relat Areas Mol Biol 38: 109-191

Folk JE, Cole PW (1966) Mechanism of action of guinea pig liver transglutaminase. I. Purification and properties of the enzyme: identification of a functional cysteine essential for activity. J Biol Chem 241(23):5518-5525

Folk JE, Park MH, Chung SI, Schrode J, Lester EP, Cooper HL (1980) Polyamines as physiological substrates for transglutaminases. J Biol Chem 255(8):3695-3700

Hu X, Zhao M, Sun W, Zhao G, Ren J (2011) Effects of microfluidization treatment and transglutaminase cross-linking on physicochemical, functional, and conformational properties of peanut protein isolate. $\mathrm{J}$ Agric Food Chem 59(16):8886-8894
Icekson I, Apelbaum A (1987) Evidence for transglutaminase activity in plant tissue. Plant Physiol 84(4):972-974

Jaros D, Heidig C, Rohm H (2007) Enzymatic modification through microbial transglutaminase enhances the viscosity of stirred yogurt. J Texture Stud 38:179-198

Jaros D, Partschefeld C, Henle T, Rohm H (2006) Transglutaminase in dairy products: chemistry, physics, applications. J Texture Stud 37(2):113-155

Jung HJ, Chen Z, Wang M, Fayad L, Romaguera J, Kwak LW, McCarty N (2012) Calcium blockers decrease the bortezomib resistance in mantle cell lymphoma via manipulation of tissue transglutaminase activities. Blood 119(11):2568-2578

Kamoun S (2001) Nonhost resistance to Phytophthora: novel prospects for a classical problem. Curr Opin Plant Biol 4(4):295-300

Kim DS, Park SS, Nam BH, Kim IH, Kim SY (2006) Reversal of drug resistance in breast cancer cells by transglutaminase 2 inhibition and nuclear factor-kappaB inactivation. Cancer Res 66(22):10936-10943

Kobayashi K, Tanita Y, Fudo R, Shinozaki J, Suzuki S, Tsuyoshi N, Yokozeki K, Yamanaka S (1998) Microbial process for producing transglutaminase. Japan Patent 0851029A1. http://www.google. com/patents/EP0851029A1?cl=en

Kuraishi C, Sakamoto J, Soeda T (1996) The usefulness of transglutaminase for food processing. In: Series AS (ed) Biotechnology for improved foods and flavors, vol 637. American Chemical Society, Washington, pp 29-38

Kuraishi C, Yamazaki K, Susa Y (2001) Transglutaminase: its utilization in the food industry. Food Reviews International 17(2):221-246

Kurakata N, Kurisu M, Yamazaki K, Soeda T (1995) Preparation of retorted food in which food material is soaked in the solution containing transglutaminase. Japan Patent 7008225

Lauber S, Henle H, Klostermeyer H (2000) Relationship between the crosslinking of caseins by transglutaminase and the gel strength of yoghurt. Eur Food Res Technol 210(5):305-309

Lentini A, Provenzano B, Tabolacci C, Beninati S (2009) Proteinpolyamine conjugates by transglutaminase 2 as potential markers for antineoplastic screening of natural compounds. Amino Acids 36(4):701-708

Lentini A, Tabolacci C, Provenzano B, Rossi S, Beninati S (2010) Phytochemicals and protein-polyamine conjugates by transglutaminase as chemopreventive and chemotherapeutic tools in cancer. Plant Physiol Biochem 48(7):627-633

Li H, Zhang L, Cui Y, Luo X, Xue C, Wang S (2013) Expression of soluble recombinant transglutaminase from Zea mays in Pichia pastoris. World J Microbiol Biotechnol 29(5):939-947

Lim TJ, Easa AM, Karim AA, Bhat R, Liong MT (2011) Development of soy-based cream cheese via the addition of microbial transglutaminase, soy protein isolate and maltodextrin. Br Food J 133(9):1147-1172

Lorand L, Graham RM (2003) Transglutaminases: crosslinking enzymes with pleiotropic functions. Nat Rev Mol Cell Biol 4(2):140-156

Lorenzen PC (2007) Effects of varying time/temperature-conditions of pre-heating and enzymatic cross-linking on techno-functional properties of reconstituted dairy ingredients. Food Res Int 40(6):700-708

Lorenzen PC, Neve H, Mautner A, Schlimme E (2002) Effect of enzymatic cross-linking of milk proteins on functional properties of setstyle yoghurt. Int J Dairy Technol 55:152-157

Macedo AJ, Sato H (2005) Propriedades e aplicações da transglutaminase microbiana em alimentos Alimentos e Nutrição. Araraquara 16(4): 413-419

Martins IM, Martins F, Belo H, Vaz M, Carvalho M, Cravador A, Choupina A (2014) Cloning, characterization and in vitro and in planta expression of a glucanase inhibitor protein (GIP) of Phytophthora cinnamomi. Mol Biol Rep 41(4):2453-2462

Marx CK, Hertel TC, Pietzsch M (2008) Purification and activation of a recombinant histidine-tagged pro-transglutaminase after soluble 
expression in Escherichia coli and partial characterization of the active enzyme. Enzym Microb Technol 42(7):568-575

Mehta K, Fok J, Miller FR, Koul D, Sahin AA (2004) Prognostic significance of tissue transglutaminase in drug resistant and metastatic breast cancer. Clin Cancer Res 10(23):8068-8076

Nielsen PM (1995) Reactions and potential industrial applications of transglutaminase. Review of literature and patents. Food Biotechnol 9(3):119-156

Noguchi T, Tanimoto H, Motoki M, Mori M (1992) A promoting material for absorption of minerals and compositions containing it. Japan Patent 04349869

Ozer B, Kirmaci HA, Oztekin S, Hayaloglu A, Atamer M (2007) Incorporation of microbial transglutaminase into non-fat yogurt production. Int Dairy J 17(3):199-207

Porta R, Giosafatto CV, di Pierro P, Sorrentino A, Mariniello L (2013) Transglutaminase-mediated modification of ovomucoid: effects on its trypsin inhibitory activity and antigenic properties. Amino Acids 44(1):285-292

Rachel NM, Pelletier JN (2013) Biotechnological applications of transglutaminases. Biomolecules 3:870-888

Reiss K, Kirchner E, Gijzen M, Zocher G, Loffelhardt B, Nurnberger T, Stehle T, Brunner F (2011) Structural and phylogenetic analyses of the GP42 transglutaminase from Phytophthora sojae reveal an evolutionary relationship between oomycetes and marine Vibrio bacteria. J Biol Chem 286(49):42585-42593

Sakai T, Kuraishi C, Sakaguchi S, Susa Y, Soeda T (1996) Pretreating food aterial having good texture by treating material with transglutaminase. Japan Patent 8332059

Sakamoto H, Kumazawa Y, Kawajiri H, Motoki M (1995) $\varepsilon-(\gamma-$ Glutamyl)lysine crosslink distribution in foods as determined by improved method. J Food Sci 60:416-420

Seguro K, Kumazawa Y, Kuraishi C, Sakamoto H, Motoki M (1996a) The epsilon-(gamma-glutamyl)lysine moiety in crosslinked casein is an available source of lysine for rats. J Nutr 126(10):2557-2562

Seguro K, Kumazawa Y, Ohtsuka T, Ide H, Nio N, Motoki M, Kubota K (1995) $\varepsilon$-( $\gamma$-Glutamyl)lysine: hydrolysis by $\gamma$-glutamyltransferase of different origins, when free or protein bound. J Agric Food Chem 43(8):1977-1981

Seguro K, Nio N, Motoki M (1996b) Some characteristics of a microbial protein cross-linking enzyme: transglutaminase. In: Parris N, Kato A, Creamer LK, Pearce J (eds) Macromolecular interactions in food technology. vol 650. American Chemical Society, Columbus, pp 271280
Serafini-Fracassini D, Del Duca S (2008) Transglutaminases: widespread cross-linking enzymes in plants. Ann Bot 102(2):145152

Serafini-Fracassini D, Della Mea M, Tasco G, Casadio R, Del Duca S (2009) Plant and animal transglutaminases: do similar functions imply similar structures? Amino Acids 36(4):643-657

Shleikin AG, Danilov NP (2011) Evolutionary-biological peculiarities of transglutaminase. Structure, physiological functions, application. $\mathrm{Zh}$ Evol Biokhim Fiziol 47(1):3-14

Tabolacci C, Lentini A, Provenzano B, Beninati S (2012) Evidences for a role of protein cross-links in transglutaminase-related disease. Amino Acids 42(2-3):975-986

Truong VD, Clare DA, Catignani GL, Swaisgood HE (2004) Cross-linking and rheological changes of whey proteins treated with microbial transglutaminase. J Agric Food Chem 52(5):1170-1176

Yamaguchi H, Wang HG (2006) Tissue transglutaminase serves as an inhibitor of apoptosis by cross-linking caspase 3 in thapsigargintreated cells. Mol Cell Biol 26(2):569-579

Yasueda H, Kumazawa Y, Motoki M (1994) Purification and characterization of a tissue-type transglutaminase from red sea bream (Pagrus major). Biosci Biotechnol Biochem 58(11):2041-2045

Yew SE, Lim TJ, Lew LC, Bhat R, Mat-Easa A, Liong MT (2011) Development of a probiotic delivery system from agrowastes, soy protein isolate, and microbial transglutaminase. J Food Sci 76(3): H108-H115

Yokoyama K, Nio N, Kikuchi Y (2004) Properties and applications of microbial transglutaminase. Appl Microbiol Biotechnol 64(4):447454

Yokoyama KI, Nakamura N, Seguro K, Kubota K (2000) Overproduction of microbial transglutaminase in Escherichia coli, in vitro refolding, and characterization of the refolded form. Biosci Biotechnol Biochem 64(6):1263-1270

Yüksel Z, Erdem YK (2010) The influence of transglutaminase treatment on functional properties of set yoghurt. Int J Dairy Technol 63:8697

Zhang F, Fang L, Wang C, Shi L, Chang T, Yang H, Cui M (2013) Effects of starches on the textural, rheological, and color properties of surimi-beef gels with microbial tranglutaminase. Meat Sci 93(3): 533-537

Zhu Y, Rinzema J, Tramper J, Bol J (1995) Microbial transglutaminasea review of its production and application in food processing. Appl Microbiol Biotechnol 44(3-4):277-282 